This item was submitted to Loughborough's Research Repository by the author.

Items in Figshare are protected by copyright, with all rights reserved, unless otherwise indicated.

\title{
Thinking with materialities in construction management: a response to Alexander Styhre
}

\section{PLEASE CITE THE PUBLISHED VERSION}

http://dx.doi.org/10.1080/01446193.2017.1348612

\section{PUBLISHER}

(C) Taylor \& Francis (Routledge)

\section{VERSION}

AM (Accepted Manuscript)

\section{PUBLISHER STATEMENT}

This work is made available according to the conditions of the Creative Commons Attribution-NonCommercialNoDerivatives 4.0 International (CC BY-NC-ND 4.0) licence. Full details of this licence are available at: https://creativecommons.org/licenses/by-nc-nd/4.0/

\section{LICENCE}

CC BY-NC-ND 4.0

\section{REPOSITORY RECORD}

Sage, Dan. 2017. "Thinking with Materialities in Construction Management: A Response to Alexander Styhre". figshare. https://hdl.handle.net/2134/25564. 


\section{Thinking with materialities in construction management:}

\section{a response to Alexander Styhre}

Alexander Styhre recently challenged Construction Management and Engineering (CME) scholarship to develop a stronger contribution to debates around materiality in mainstream management and organization studies. The rationale for his challenge is that CME scholars have a unique engagement with an important materiality - the built environment - that affords them a significant, yet largely unrealized, potential to inform wider debates about the materiality of social and organizational life. In my response here I do not disagree with Styhre’s overall argument. Instead I critically reflect, via a discussion of two themes implicit within his proposals - hiddenness and managerial power - on the rather unitary formulation of his argument. In so doing I do not so much seek to flag up challenges as to enliven his proposals by discussing the breadth of opportunities for contribution presented to CME academics in engaging with materialities with general management and organization scholarship.

Keywords: materiality, power, managerialism, construction management, journal rankings, critical social theory

In a gently provocative article, Styhre (2017) argues that construction management and engineering (CME) scholarship can and should do more to inform the wider study of materiality. Styhre (2017) rightly acknowledges that CME scholarship has made considerable progress in theorizing materiality in the last decade, referencing diverse contributions, such as Lees and Sexton (2014), Harty (2005) and Tryggestad et al. (2010). However, he then goes on 
to claim that the CME academic community has tended to develop studies of materiality in a manner that fails to make the most of the empirical opportunities presented to inform wider debates about materiality in mainstream management and organization studies (MOS) journals and other social sciences. In other words, theories and concepts of materiality (e.g. actor-theory theory, neo-institutional theory, and epistemic objects) have been imported into the study of construction, but far more seldom has a CME view been harnessed to inform the development of such theories. My response to this argument is not to nit-pick the strength of Styhre's assumptions by pointing out CME scholarship on materiality published in mainstream MOS journals (e.g. Ewenstein and Whyte, 2009; Pink et al. 2017; Sage et al. 2016). To do so not only risks reducing substantive intellectual debate into a rather superficial argument over bibliographical searching, but also clearly supports Stythre’s (2017) general argument about the potential for CME scholars wider theoretical influence. I will also set to one side the temptation to rehearse long-standing calls for more methodological diversity in CME scholarship which may be more commensurate with considerations of materiality (see Pink et al. 2012). Instead, I will focus upon two more theoretical themes that remain more or less implicit within his thinking about materiality: hiddenness and managerial power. I discuss these themes to develop, rather than detract from, his specific argument - indeed I remain largely sympathetic to his provocation - while also raising some important strands of thinking about materiality which remain less commonly articulated in CME scholarship.

\section{The hiddenness of materiality}

It might appear rather surprising to argue for the centrality of hiddenness in a discussion of something seemingly so concrete and present to human beings as materiality. Yet, in many 
diverse ways, hiddenness has long been a central concern in thinking about materiality, as with Styhre (2017). The concern with the material thing as hidden can be traced across various authors and approaches such as: Martin Heidegger’s (1977: 7) phenomenology of technology as a (forced) revealing of hidden forces (e.g. the power of the prehistoric sun in a coal power station); Bruno Latour's (1992: 153-4) exposition of the black boxed 'missing masses', such as the speed bump, hidden in plain sight in sociological thought; through the emphasis on the hidden real properties of material things, including hammers, in the object orientated philosophy of Graham Harman (Harman, 2009: 195-6); to the hidden potential of nonhuman things to affect, and be affected by, each other as constituted by assemblages in SpinozoDeleuzian considerations of affect (e.g. Anderson, 2014: 10; DeLanda, 2016). Thinking about material things, whether paper clips or oil rigs, it seems, demands some acknowledgment of their hiddenness to human beings.

Styhre (2017) too writes a lot about the specific hiddenness of material objects to humans. Paralleling Latour's (1992) argument on the black boxed 'missing masses' (1992), he suggests technology is developed 'preferably to the point where the very materiality of the technology is overlooked and ignored in common sense thinking' (Styhre, 2017: 36). Working with a more Heideggerian sensibility, he goes on to explain how 'materiality is revealing itself to humans as technology' (p37). Elsewhere he adopts a somewhat more Harmanian view when he explains 'humans have at best a partial understanding of how technology affect their everyday lives, and many technology remains ambiguous unexplored or event to some extent mysterious to the everyday users' (p40). In places, he also evokes Spinozo-Deleuzian thinking as when he discusses technology as ‘an assemblage’ (p37), part material, part social. 
By implicitly registering these different theoretical approaches to the hiddenness of materiality, something else remains more problematically hidden in Styhre's thinking: these ways of thinking of materiality and hiddenness emerge from very different approaches to materiality that have often been said to be incommensurate. For instance, the rather Harmanian notion that material objects possess some sort of hidden reality, or remain 'mysterious' as Styrhe (2017: 40) puts it, has been said by Harman (2009) to be ontologically incommensurate with Latourian notions of material objects as fully constituted by their actual relations. Likewise, both of these approaches themselves diverge from more Spinozo-Deleuzian understanding of material objects as composed from their circulating potential, or affective capacities, for relations (compare e.g. DeLanda, 2016 and Harman, 2009), and, in turn, from Heideggerian phenomenology (see Latour et al. 2011). In order to unpack this point further I will compare Harman's (2009) object orientated philosophy with Latour's (1988; 1992) actor-network theory. Significantly, Harman (2009) works within a realist proposition that 'the world is composed of countless layers of withdrawn real things' (p215). To understand the implication of this proposition, and how it departs from Latour's thinking about materiality, Harman (2009) elaborates the example of a broken hammer:

... the hammer has hammer-qualities [e.g. we can use it to build a house] not found in its pieces. Moreover, these hammer-qualities are not just functional effects on the environment, since the hammer has other untapped hammer-qualities than those currently registered by neighbouring things [e.g. it can be used to knock down a house].

The difference from Latour’s (1988) relational ontology is stark, as this passage from Latour, as quoted by Harman (2009: 25), demonstrates: 
... others, who define me, link me up, make me speak, interpret what I say, and enrol me. Whether I am a storm, a rat, a rock, a lake, a lion, a child, a worker, a gene, a slave, the unconscious, or a virus, they whispher to me, they suggest, they impose an interpretation of what I am and what I could be (Latour, 1988: 192).

Importantly for Latour (1988; 1992), though perhaps not all actor-network theorists, objects appear fully constituted by their assembled relations, and it is the intersections in these shifting relations that enable both stability/change; whereas, instead, for Harman (2009), an aspect of their reality must always remain hidden or mysterious in order to understand how objects stabilize as their parts change, or change as this withdrawn reality comes to the fore (for more on this heated discussion see also Bennett, 2015; Latour et al. 2011). What is more, in Latour (1988; 1992), objects that are hidden to human beings are those that are 'black boxed', predictable, lacking active agency - the hammer that always works as it should. In contrast, for Harman (2009), the hiddenness of objects from human beings corresponds with their agency to act in unruly ways - the potential for the hammer to become something new. To my mind these specific philosophical differences are important in and of themselves, and should be acknowledged more than Styhre (2017) asks of CME scholarship. But more widely, my retelling of this debate around hiddenness, and its intersections with themes discussed by Styhre, such as material agency, serves a broader purpose. Namely, I intend it to act as an important caution: in mobilizing, and especially contributing, to wider theoretical debates around materiality, CME scholarship must remain cognisant of the diverse, and sometimes antagonistic, intellectual currents at work. It is all too easy when stood at a sufficient distance from a body of intellectual work, as with any body perhaps, to fail to notice its finer details, 
fissures and complexities (for more examples of this point see relatedly Schweber, 2016). If CME scholars are to successfully contribute to wider debates around materiality they must avoid consuming analytically nullifying reductions of materiality by paying attention to, rather than downplaying, these important, and long-standing, intellectual divergences.

\section{Materializing power - from building sites to journal lists}

I will now draw attention to another theme underplayed in Styhre's (2017) argument: the role of managerial power in thinking materiality. The lack of discussion of managerial power, and indeed management, or power, more generally, is rather surprising because elsewhere Styhre has written extensively about the operation of managerial power and politics in construction and beyond (e.g. Styhre, 2006; 2011; Styhre and Börjesson, 2011). However, here, he offers only two passing references to how buildings can circulate power and attendant political interests and agendas. Instead he elects to structure his argument first around more philosophical concerns (e.g. socio-materiality, agency), then the materiality of engineering judgement and expertise, and finally, turning to construction more specifically, his analysis centres upon the significance of the built environment as a social technology. While these strands of inquiry are surely of interest to CME scholars, many will be as, if not, for some at least, more, interested in how specific construction objects, whether volumetric building systems, Building Information Modelling, 3D printing or robotics, relate to practices of management. To be fair, Styhre (2017) does gesture in this direction when he gestures towards how material systems, including building components, may be employed to effectively delimit, or control, (construction) engineering expertise and judgement (p39). Unfortunately, this discussion of managerial power is very brief, and moreover it does not admit how more 
informal forms of managerial power are materially mediated. For example, the use of site objects as props in pranks for new entrants (e.g. asking new workers to hold a bucket to collect sawdust from a drill, or look for the long weight/wait). Importantly, these material objects and relations may not simply reproduce formal management power relations, they may also indicate the emergence of new ones which can be orthogonal, even inimical, to those formal hierarchies.

What is also not acknowledged at all by Styhre (2017) is that the materiality of managerial power also implicitly frames the specific concluding proposal his argument builds up towards: that CME scholars make a contribution to 'so-called top tier journals, in the ABS $4 *$ journals and elsewhere’ (p43). In discussing this topic here my purpose is not to engage in a discussion of whether Styhre (2017) is an ABS (Association of Business School) list exponent or detractor; rather my aim here is twofold. First, and perhaps more importantly, I wish to draw greater attention to the wider consequences of CME scholars forming attachments to material bodies, such as the ABS lists as Styhre (2017) suggests they should. And secondly, the ABS list offers a vivid example of how power and (academic) knowledge intertwine with material forms, practices and infrastructures.

I begin my discussion by risking to labour the obvious: all scholarly knowledge, including a journal like Construction Management and Economics, is not simply a disembodied repository of ideas, it is a material thing and it is this materiality which allows it to relate to other bodies, human and nonhuman, and which influences how academic knowledge develops. And importantly, it is this materiality, whether comprised of paper and ink or computer circuitry and electrons, which enable a certain geometry of power to take shape across various human actors: publishing houses, editors, reviewers, authors, academic institutions, subscription 
revenues, university managers and academic readers et cetera. These power geometries include the often commented upon editorial censure of work critical of established research paradigms (Wilmott, 2011), the accessibility of that work to globally richer, institutionally affiliated scholars, and the asymmetrical relationship between academic labour and the profit of corporate publishers. The presence of journal quality lists, such as the ABS Journal Quality Guide, or 'ABS list' for short, provides a particularly vivid example of how the introduction of a new material object, as Styhre (2017) proposes for CME scholarship, has reshaped, and could yet reshape, such power geometries. It is important to state at this juncture in my argument that while the ABS list is intended for use in UK Business Schools, journal quality lists are used globally across numerous disciplines which more or less resemble the ABS list (e.g. those produced by the Centre National de la Recherche Scientifique and the Australian Business Deans Council). Nevertheless, to develop my point further for an international CME audience first requires some understanding of the specific origins, and institutionalization, of the ABS list and ensuing critique.

The ABS list is a journal quality list that has been published, revised and expanded by a group of 10-30 senior academics supported the Association of Business Schools (ABS) since 2007. The list currently list ranks 1401 English language journals across a wide variety of fields where business school academic might publish, from accountancy and finance through the social sciences to sector specific domains, including construction and the built environment. Journals are ranked using a combination of metrics (citation data, impact factors) and academic judgement. The stated purpose of the list is: 'is to provide a level playing field. Emerging scholars will have greater clarity as to which journals to aim for, and where the best work in their field tends to be clustered. By the same measure, publication in top journals gives scholars a recognised currency on which career progress can be based' (ABS, 2017). Another, less often 
emphasized, though highly significant purpose for the list is that it helps Deans and Heads of Department of Business Schools in the UK, and beyond, to monitor, evaluate and optimise, decisions around the career development of individual academics (Wilmott, 2011).

The assumed efficacy of the ABS list belies both repeated criticisms of its poor correlation with government audits for research funding (such as the United Kingdom's Research Excellence Framework) and its inhibition of academic innovation and autonomy (Hussain, 2015; Wilmott, 2011). What is less commonly addressed is that the legitimacy of this list, while clearly derived from its symbolic value for humans - 'should personal networks deny its currency in one institution, there will be others who will recognise and welcome it' (ABS, 2017), also stems from more material things and relations. That is to say, to operate as an object of managerial power, the ABS list involves a set of material practices, forms and infrastructures (e.g. desk drawers, PC, printers, web forums) that allow it to travel and connect with other bodies, such as employee appraisal systems, research performance audits, and other academic management processes

To understand the material aspects of the power of the ABS list, it is important to stress that the list requires a widespread presence; this is because as well as offering a tool for managers, the ABS list also imbues a decidedly panoptic form of power over academic researchers enabling them to internalize, or 'fetishize' (Wilmott, 2011), it as an object of their (masochistic) judgement (Tourish and Wilmott, 2015: 39). After all, if the list was only available to Deans and Heads of Departments, publications could only be judged retrospectively rather than decisions made proactively about where to publish. Onus is to be placed on the individual academic to consult the list when deciding where to publish: 'Emerging scholars will have 
greater clarity as to which journals to aim for, and where the best work in their field tends to be clustered' (ABS, 2017). Opposed to such benignly functional interpretations, Hugh Wilmott, a member of the UK REF (Research Excellence Framework) 2014 panel for Business and Management, describes the effect of this internalization process as highly problematic:

Garrotting scholarship in this manner can only diminish the distinctiveness, damage the reputation and decrease the public flow of funds to UK business schools. If the ABS 'world elite' list of journals becomes the benchmark, or even the beacon, of 'worldleading’ research, scholarship will be further homogenized and innovation stifled (Wilmott, 2011: 439).

More recently, Tourish and Wilmott (2015) have been clearer still on what they perceived are the deleterious consequences of the widespread reification of the ABS list in UK business schools:

The most prized academics are then the ones who have proved most skilful in limiting their research agenda, restricting their theoretical frameworks and narrowing their choice of method to what is congenial to 'top' journals. Such bankrupt scholarship pays scant attention to the critical questions that must be asked if business and management schools are to engage meaningfully with the deepening problems (e.g. of sustainability and social justice) that beset society. (Tourish and Wilmott, 2015: 45). 
Such criticisms of the ABS list are especially concerning in the light of Styhre's (2017) mention of its increased use by CME scholars. This is because the stifling of innovation is, as Tourish and Wilmott (2015: 42) rightly acknowledge, especially damaging for those in business schools looking to engage in more domain specialist and interdisciplinary research; in other words, the ABS list is likely already likely inhibiting, not furthering, engagement between mainstream MOS and CME scholarship.

Moving beyond the substance of ongoing critiques, it is notable that such discussions (e.g. Hussain, 2015; Wilmott, 2011; Tourish and Wilmott, 2015) have afforded remarkably little attention to the materiality of the guide. This is especially curious because it seems clear to me, and in keeping with Foucault's (1977/1995) understanding of panoptic power, that the widespread presence of the list, and by extension its specific panoptic power, also requires a specific set of material forms, practices and infrastructures. That this is the case became clear in 2015 when after launching its new Journal Guide the ABS switched to website only viewing for registered users its (purportedly to enhance viewability). In the days, if not hours, after its availability, individual business school academics were quick to convert the list into a PDF file to aid its wider distribution. Initially, at least, this distribution process was only mediated by business school academics via email using informal forums and email address books. If the list had remained only accessible online, or perhaps restricted to ABS members, or even registered business schools, its agency, and thus its managerial power to influence wider research, including that within CME scholarship, would have been substantially diminished. But instead the power of this object multiplied, and it did so because of its materiality: it possessed a latent capacity, as Delanda (2016) might put it, presumably tolerated, if not sanctioned, by the ABS themselves, to be informally converted into a PDF file, emailed, distributed on forums, hosted on institutional and personal websites, saved on PCs, printed and left in desk drawers for the 
next submission decision. What is striking here is that in a rather remarkable turn of events, the panoptic power of the ABS list was uncritically, almost automatically, extended by rank and file academics, not business school Deans. These academics were not simply being disciplined as they internalized its managerial gaze, they were opting to extend its gaze further in space and time.

My discussion of the ABS list here is intended to serve two purposes. First, through it we can start to raise critical questions regarding Styhre’s (2017) seemingly unreflective proposal that CME scholars engage with the capacities of this specific object to affect them and be affected by it. By predicating engagement with mainstream management through the ABS list, CME scholars may unwittingly be 'hoist by their own petard' as they find themselves engaging in a process orientated to stifle rather than encourage innovative research across disciplines. Perhaps instead focus should be placed, as Wilmott (2011) proposes, on the substance of innovative intellectual inquiry to enable more dialogue between the two areas of scholarship, for example: the ubiquity of the built environment in all organizational and management practices, the rising significance of project-based, fragmented and precarious work organizational forms, and the significance of global challenges related to the built environment (e.g. housing, climate change, energy security, demographic shifts etc.).

Secondly, the example of the ABS list also sheds light on the profoundly material dimensions of relations of power within organizational contexts, whether UK Business Schools or construction contractors. The ABS list demonstrates how a material object, whether a paper or electronic version, was rendered integral not just to translating the neutral value of scholarship, but attempts at (self) disciplining, and segmenting, employees. Drawing upon the four different 
approaches to materialities I introduced earlier in this paper we might understand the materiality of power in at least four ways by virtue of this example. For Heideggerians, the list demonstrates the revealing of the power of instantaneous electronic communications, the electron, over, for example, the postal system, to perhaps reduce people into bare instruments of managerial power. For Latourians, the break down and repair of the distribution of the 2015 list, reveals the prior work that managers, and employees, have undertaken to ensure its smooth circulation among employees (including its physical reproduction and linkage to PDR systems). For Harmanians, the case of 2015 list might reveal how it contains real latent properties which, on this occasion, enabled its widespread circulation as it was it was related to other actors (Deans, managers, PDF processing software, email systems). While for Deleuzo-Guattarians, these hidden properties are not entirely found within the object itself the physical list - but constructed through an assemblage of interacting entities within and beyond the object that affect and are affected by each other. Managers, and employees, might thus experiment with these trans-personal affects, learning how they interact, asking what the ABS list can do if they take it apart or plug it into another assemblage (like, for example, CME scholarship), in order to develop new techniques that reproduce or challenge power geometries.

\section{Conclusion}

My discussion here of the materiality of hiddenness and managerial power is intended to enliven rather than nullify Styhre's (2017) provocation to CME scholars. To repeat - I am highly supportive of any proposal that CME scholars can, and should, make a stronger contribution to mainstream management and organizational studies, and indeed others domains across the social sciences (see e.g. Sage, 2013). I am also convinced too that research around 
materiality offer a particularly fertile conduit for such engagement. However, to my mind, Styhre's (2017) provocation is rather hamstrung by its somewhat unitary orientation. This is evident both theoretically, in terms of his lack of consideration of the competing philosophical currents at work within wider debates around materiality, as well as in his tendency to gloss over consideration of the materiality of managerial power and politics, not least the consequences of forming new intellectual attachments with managerial objects such as the ABS list. If CME scholars do not pay serious attention to these more pluralist and critical precepts they risk underplaying both the challenges and opportunities in thinking materialities with general management and organizational scholars.

\section{References}

ABS (2017) Academic Journal Guide 2015, Chartered Association of Business Schools, https://charteredabs.org/academic-journal-guide-2015/ (accessed $4{ }^{\text {th }}$ May 2017).

Anderson, B. (2014) Encountering Affect: Capacities, Apparatuses, Conditions, Ashgate: Farnham.

Bennett, J. (2015) Systems and Things: On Vital Materialism and Object-Orientated Philosophy, in R. Grusin (Ed.) The Nonhuman Turn, University of Minnesota Press: Minneapolis, pp223-240. 
DeLanda, M (2016) Assemblage Theory, Edinburgh University Press: Edinburgh.

Ewenstein, B. and Whyte, J. (2009) Knowledge Practices in Design, Organization Studies, 30(1), 7-30.

Foucault (1977/1995) Discipline and Punish: The Birth of the Prison, Vintage Books: New York

Harty, C. (2005) Innovation in Construction: A Sociology of Technology Approach, Building Research and Information, 33(6), 512-522.

Harty, C. (2008) Implementing innovation in construction: contexts, relative boundedness and actor-network theory, Construction Management and Economics, 26(10), 1029-1041.

Harman, G. (2009) Prince of Networks: Bruno Latour and Metaphyics, re Press, Melbourne: Victoria.

Heidegger, M. (1977) The Question Concerning Technology and other essays, HarperPerennial: New York. 
Hussain, S. (2015) Journal list fetishism and the 'sign of 4' in the ABS guide: A question of trust?, Organization, 22(1), 119-138.

Latour, B. (1988) The Pasteurization of France, Harvard University Press: Cambridge.

Latour, B. (1992) 'Where Are the Missing Masses? The Sociology of a FewMundane Artefacts, In W Bijker and J Law (eds), Shaping Technology-Building Society. Studies in Sociotechnical Change, MIT Press: Cambridge Mass, pp.225-259.

Latour, B. Harman, G. and Erdélyi, P. (2011) The Prince and the Wolf: Latour and Harman at the LSE, Zero Books: Winchester, UK.

Lees, T. and Sexton, M. (2014) An evolutionary innovation perspective on the selection of low and zero-carbon technologies in new housing. Building Research and Information, 42(3), 276-287.

Pink, S. Tutt, D. and Dainty, A. (2012) Introducing ethnographic research in the construction industry. In Pink, S. Tutt, D. and Dainty, A. (eds) Ethnographic Research in the Construction Industry, Routledge: London, pp. 1-22.

Pink, S. Lingard, H. and Harley, J. (2017) Refiguring creativity in virtual work: the digitalmaterial construction site, New Technology, Work and Employment, 32(1), 12-27. 
Rowlinson, M. Harvey, C. Kelly, A. Morris, H. and Todeva, E. (2015) Accounting for research quality: Research audits and the journal rankings debate, Critical Perspectives on Accounting, 26, 2-22.

Sage, D. (2013) ‘Danger building site - keep out!?’: a critical agenda for geographical engagement with contemporary construction industries, Social and Cultural Geography, 14(2), 168-91.

Sage, D. Justesen, L. Dainty, A. Tryggestad, K. and Mouritsen, J. (2016) Organizing space and time through relational human-animal boundary work: Exclusion, Invitation and Disturbance, Organization, 23(3) 434- 450.

Schweber, L. (2016) Putting theory to work: the use of theory in construction research, Construction Management and Economics, 33(10), 840-860.

Styhre, A. (2006) The bureaucratization of the project manager function: The case of the construction industry, International Journal of Project Management, 24, 271-276.

Styhre, A. (2011) The overworked site manager: gendered ideologies in the construction industry, Construction Management and Economics, 29(9), 943-955. 
Styhre and Borjesson (2011) Project management in the culture industry: Balancing structure and creativity, International Journal of Project Organization and Management., 3(1): 22-35.

Styhre, A. (2017) Thinking about materiality: the value of a construction management and engineering view, Construction Management and Economics, 35 (1-2), 35-44.

Tourish, D. and Wilmott, H. (2015) In Defiance of Folly: Journal rankings, mindless measures and the ABS Guide, Critical Perspectives on Accounting, 26, 37-46.

Tryggestad, K. Georg, S., and Hernes, T., (2010) Constructing Buildings and Design Ambitions, Construction Management and Economics, 28(6), 695-705.

Wilmott, H. (2011) Journal List Fetishism and the Perversion of Scholarship: Reactivity and the ABS List, Organization 18(4): 429-42. 